\title{
Endodontic Therapy of a Mandibular Premolar with Three Root Canals - Two Case Reports
}

\author{
Jugoslav Ilić, Mirjana Vujašković, Ružica Nedeljković \\ Department for Restorative Dentistry and Endodontics, Faculty of Dentistry, University of Belgrade, Belgrade, Serbia
}

\begin{abstract}
SUMMARY
The most important requirements for successful endodontic treatment are accurate diagnosis and good knowledge of canal morphology. A mandibular second premolars rarely have more than one root and one root canal. Data from the literature indicate low percentage of a mandibular premolars with three or more root canals. Unusual morphology of the root canal system is diagnostic and therapeutic challenge. It is very important to analyze preoperative radiograph and to explore thoroughly the entrance of the root canal. The aim of this study was to present two patients who had lower second premolars with three canals that required endodontic therapy.
\end{abstract}

Keywords: mandibular second premolar; anatomical variations; endodontic treatment

\section{INTRODUCTION}

Knowledge of root canal morphology is a prerequisite for successful endodontic treatment together with good analysis of the preoperative radiographs and careful exploration of pulp chambers $[1,2]$. A retroalveolar radiograph is not sufficient to make correct diagnosis of all abnormalities and morphological variations of the root canal. Loss of a clear shadow of the main root canal may predict the occurrence of double or more canals, requiring further analysis and special attention during endodontic procedure.

Endodontic therapy considers chemomechanical treatment of a root canal, disinfection, shaping and hermetic obturation as well as crown reconstruction to prevent a reinfection $[2,3]$. The main cause of the endodontic treatment failure is inadequate preparation and obturation of the root canal [2]. The other reasons for the failure could be complex, untreated or forgotten canals $[3,4]$.

Mandibular premolars usually have a single root and one root canal. Morphological variations in the position and number of canals are present in about $30 \%$ of cases [ 5 , 6 , 7]. According to their root canal morphology, Vertucci [8] has described five types of lower premolars. Type I has a single root canal from the pulp chamber to the apex of the tooth; type II has a canal that starts from pulp chamber and then branches into two canals which joins again into one on the apex; type III has two separate canals from the pulp chamber up to the apex; type IV considers a single root canal which branches into two canals on the apex; type V starts as one canal from pulp chamber and branches into three separate root canals.

Mandibular second premolar usually has one root and one canal despite variations in the number and morphology of the canal and numerous branches of the main root canal in cervical, medial or apical third [7, 9]. From 400 examined lower premolars, Vertucci [8] reported a single root canal in approximately $97.5 \%$, while 2 or 3 canals were found in $2.5 \%$. In the study done by Zilich \& Dowson [10] from 938 examined teeth, $12.1 \%$ had two or more roots and $0.4 \%$ samples had three root canals. Lower second premolars with three canals were also reported by other authors $[7,11,12]$. Some authors described the lower second premolar with four or five canals $[6,13]$. Martzi \& Zmener [14] have described a unique case having five canal entrances in one root.

The aim of this study was to report two patients who had lower second premolars with complex root canal morphology and to present the complexity of endodontic procedure.

\section{CASE REPORT 1}

A 24 year-old man was referred to the Clinic for Restorative Dentistry and Endodontics at the School of Dentistry in Belgrade for the endodontic treatment of the left lower second premolar. Tooth was asymptomatic and with temporary filling. Tooth was slightly more sensitive on percussion test compared to the control tooth (the first lower premolar). Electric pulp test showed increased threshold. Endodontic treatment was necessary. From the radiography taken preoperatively (Figure 1), the existence of complex root systems was determined.

After anesthetizing lower inferior nerve (Lidocaine 2\% + adrenaline 1:200000, Galenika ad, Serbia) temporary filling was removed and access cavity, oval shape in buccolingual direction, was formed. At the bottom of the pulp chamber, the two canal openings (buccal and lingual) were clearly observed. The root canal openings were flared by Gates Gliden drills FKG Dentaire, Switzerland). K file \# 
10 (FKG Dentaire, Switzerland) was used for root canals exploration as well as for odontometry (Figure 2).

Distal angulations of the instrument placed in the buccal canal as well as additional shadow observed at $\mathrm{x}$-ray radiogram in the apex of the root increased the possibility of additional root canals. The access cavity was modified by extension of the buccal edge in mesiobuccal direction giving the cavity triangular shape (Figure 3). Careful exploration of the buccal part of the pulp chamber floor identified another root canal mesially. An additional radiography was taken with the three instruments in order to verify the position of root canals (Figure 4). Existence of the three root canals: mesiobuccal, distobuccal and lingual canals was verified. Final working length for all canals was determined by apex locator (Raypex ${ }^{\oplus} 4$, VDW, Germany).

Root canals were instrumented using hand instruments (FKG Dentaire, Switzerland) and double cone technique with copious irrigation of $1 \% \mathrm{NaOCl}$. For canal lubrication Glyde (Dentsply-Maillefer, Switzerland) was used. Final instrumentation of the apical part of the canals

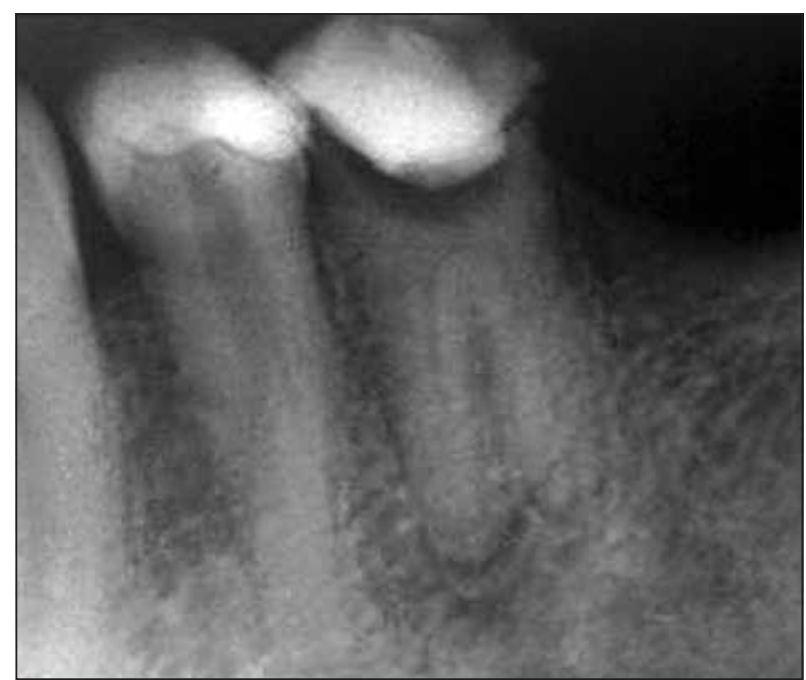

Figure 1. Preoperative radiography of the tooth 35

Slika 1. Properacioni radiogram zuba 35

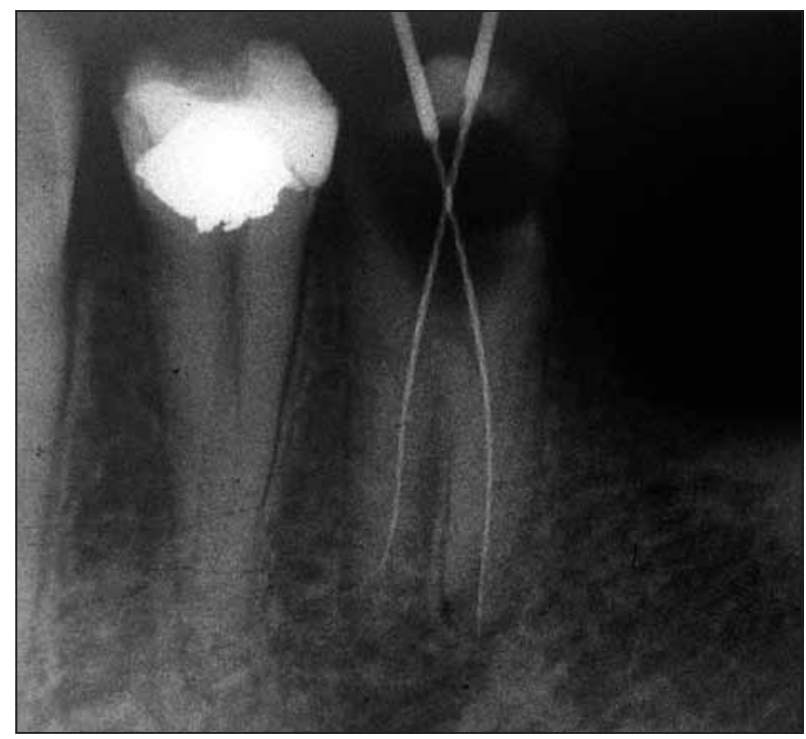

Figure 2. Radiography with the two instruments into canals (lingual and buccal)

Slika 2. Radiogram sa dva instrumenta u kanalu (lingvalni i bukalni)

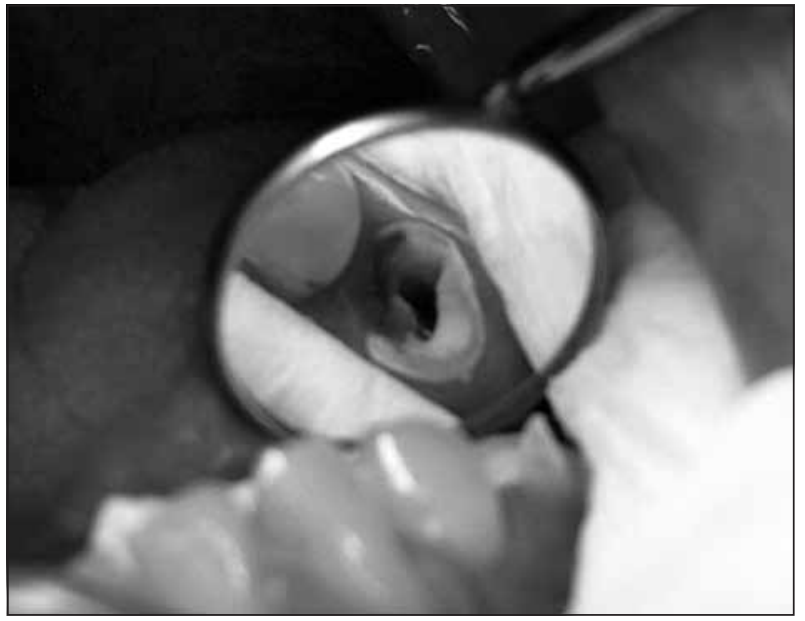

Figure 3. Triangular shape of the access cavity Slika 3. Trouglasti oblik trepanacionog otvora

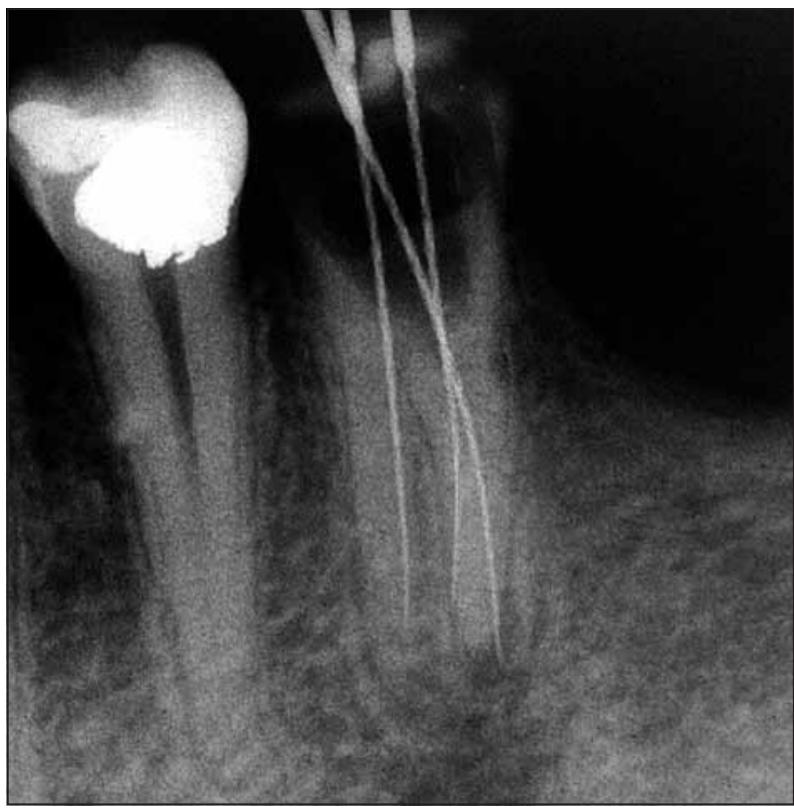

Figure 4. Radiography with the instruments in all three canals Slika 4. Radiogram s instrumentima u sva tri kanala

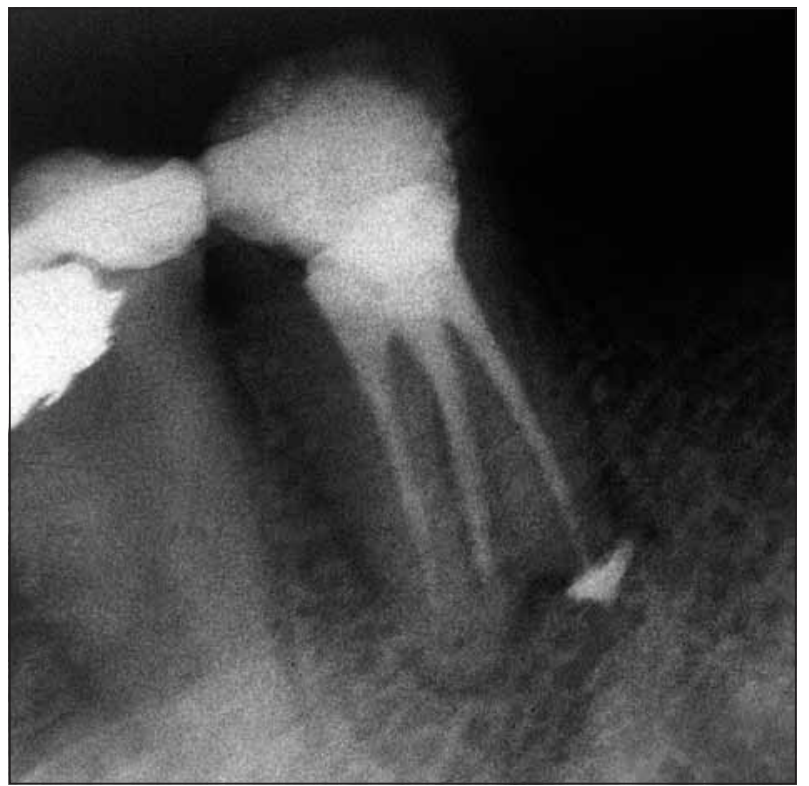

Figure 5. Obturation of the root canal Slika 5. Konačno kanalno punjenje 
was using \#25 instrument. Once instrumentation was completed, the canals were flushed with $10 \%$ citric acid, dried with paper points (FKG Dentaire, Switzerland) and medicated with Endocal ${ }^{\circ}$ (Septodont, France) for seven days. The temporary filling was Citodur (Austria). At the next appointment, temporary filling and medication from the root canals were removed; the canals irrigated with $1 \% \mathrm{NaOCl}$, dried and obturated by single cone technique using paste RSA RoekoSeal ${ }^{\circ}$ (Roeko, Germany) and gutta-percha points. Figure 5 shows dental radiography after obturation.

\section{CASE REPORT 2}

A 56-year-old woman presented at the Clinic for Restorative Dentistry and Endodontics, School of Dentistry in Belgrade because of mild, spontaneous but long-lasting pain in the area of the left mandubular first premolar. Clinical examination of the suspected tooth showed large caries lesion, the percutory test was normal. The electric pulp test showed increased threshold compared to the control tooth, intact right first premolar. Based on the clinical evidence, a chronic dental pulpitis was diagnosed and endodontic therapy was required. Preoperative radiogram analysis (Figure 6) indicated the complex morphology of the teeth based on the three periodontal lines in the apical part of the tooth while root canal shadows were multiple, vague, and dashed. Those findings suggested precaution during all phases of endodontic treatment to avoid potential therapeutic errors.

After giving anesthesia for lower alveolar nerve (Lidocaine 2\% + adrenaline 1:200000, Galenika, Serbia), caries lesion was removed and access cavity was prepared. Cavity shape was modified in a triangle which is uncom- mon for premolars because of the assumption from the radiogram of three roots, meaning three or more canals. The base of the triangle was buccal surface and the top was formed orally. After coronal pulp removal, the entrance to the lingual canal was easily identified. Careful explorations of the canal by K file \# 10 (FKG Dentaire, Switzerland) showed one lingual canal only. In the buccal part of pulp chamber, one entrance to the canal was found. Careful exploration with \#10 along the walls revealed branching of the buccal canal in mesial and distal canal in the coronal third of the canal. Peso drill \# 4 and \# 3 (FKG Dentaire, Switzerland) was used to flare canal entries in order to enable straight-line approach to buccal mesial and distal canal. Final working length for all canals was determined by Apex locator (Raypex ${ }^{\oplus} 4, \mathrm{VDW}$, Germany) and confirmed radiographically (Figure 7).

Coronal-thirds of the canals were processed by Peso drill while middle and apical thirds were instrumented by hand instruments (FKG Dentaire, Switzerland) using the technique of double cone with copious irrigation of $1 \% \mathrm{NaOCl} \mathrm{lubrication} \mathrm{by} \mathrm{Canal} \mathrm{Plus}{ }^{\circ}$ (Septodont, France). Final instrument used in apical preparation of the canals was \# 25. The root canals were finally flushed with $10 \%$ citric acid and dried with paper points (FKG Dentaire, Switzerland). Obturation was conducted by lateral condensation of gutta-percha points and paste Acroseal ${ }^{\circ}$ (Septodont, France). Radiography after obturation is shown at Figure 8.

\section{DISCUSSION}

Anatomical variations of mandibular premolars are documented in the literature. Although the occurrence of premolars having three root canals is extremely rare, each case

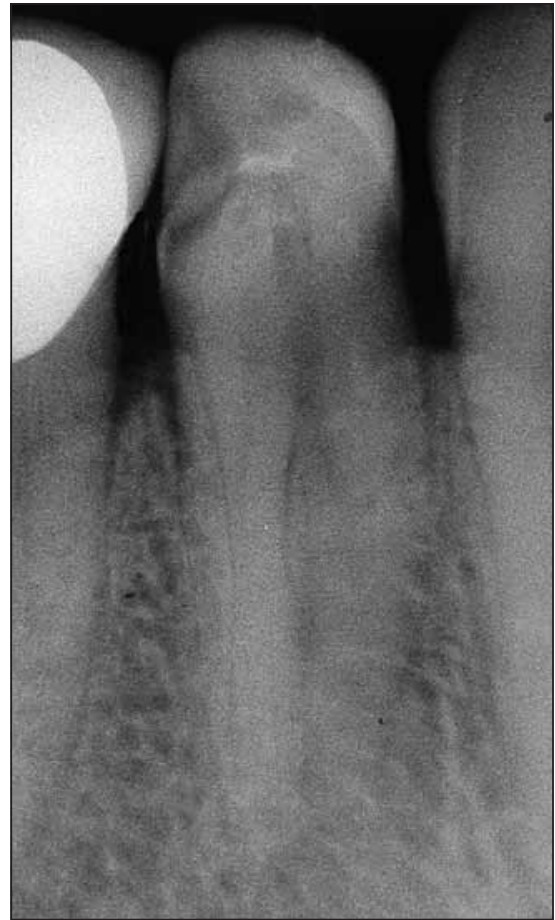

Figure 6. Preliminary radiography (tooth 35) Slika 6. Primarni dijagnostički snimak (zub 35)

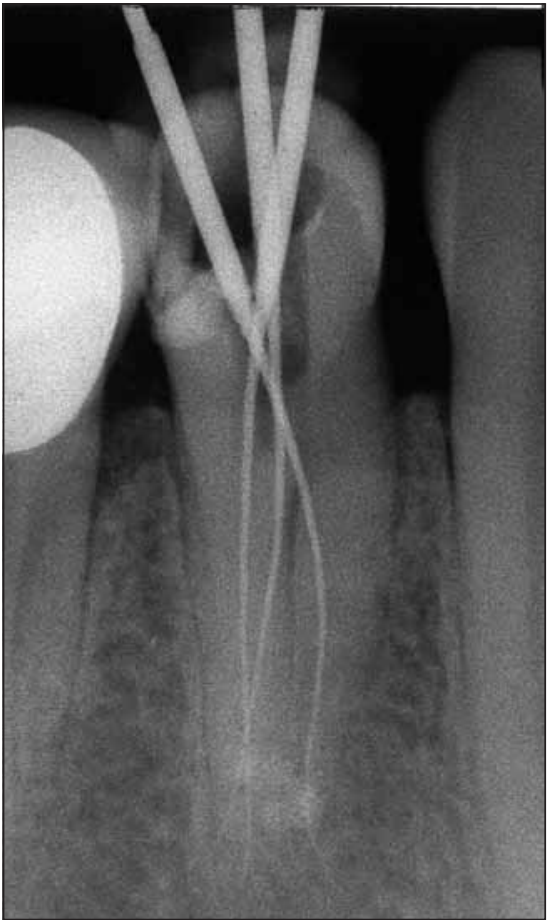

Figure 7. Odontometry Slika 7. Odontometrija

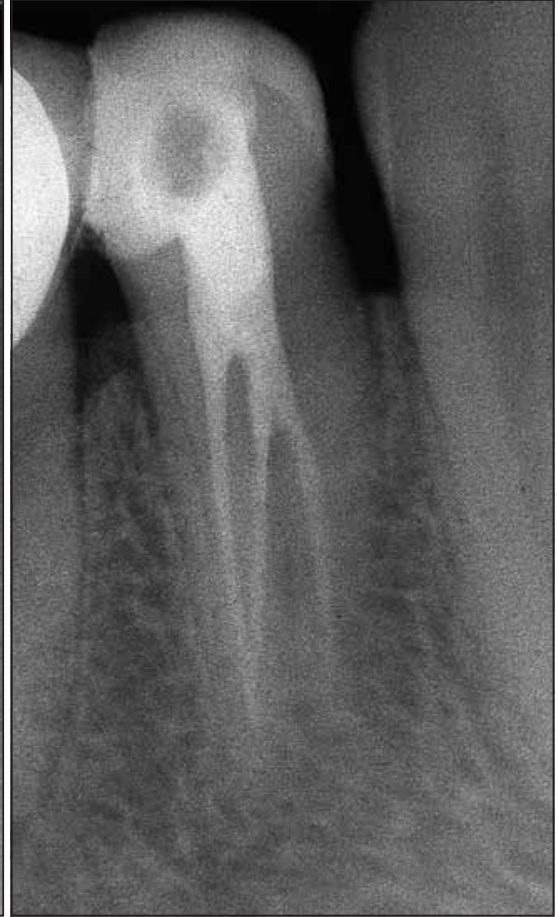

Figure 8. Obturation

Slika 8. Konačna opturacija 
must be carefully analyzed clinically and radiographically. Endodontic treatment of premolars with three root canals is highly demanding procedure from the beginning to the end of the treatment and numerous precautions should be considered.

Preoperative radiography is an introduction to this complex process and very important step in the diagnosis of multiple canals of lower premolars $[15,16,17]$. If analysis is done carefully, disappearance of the main canal shadow may suggest the possibility of doubling the canal. Some times narrow canals can be evident. This is an indication of unusual morphology and attention should be paid during the preparation of the access cavity and exploring the canals. Use of magnifying glass or endodontic microscope is inevitable assistance in registering the position of the entrance to the root canal.

Exploration of pulp chamber of a premolar with three canals most commonly will reveal single lingual canal and the two buccal (mesial and distal). One of the premolars described in this study had three roots (lingual, mesiobuccal and distobuccal) and the same number of the canals. The other one had two roots (lingual and buccal) and buccal root had two canals (mesiobuccal and distobuccal). In such cases, when the canals are narrow, it is difficult to reach glide path. Exploration has to be done by canal instruments \#08 and \#10 and using a lubricant. Basically, two or more radiographs should be done with the difference about 30 degrees mesially or distally to avoid canal superimposing.

In addition to accurate diagnosis, such complex morphology requires careful endodontic treatment and odontometry with a combination of radiographic methods when instruments are positioned into the canal canals and angles of radiography are changed to avoid superposition and accurately register the working length. Use of apex locator is significant because it is more precise method and reduces the number of radiograms. Rotary instrumentation of the entrance to the root canals is important to create straight access for the canal instruments. It is of great importance especially in doubled canals, because it reduces curvature and allows access to the curved apical portion of the tooth. Adequate obturation and selection of the main gutta-percha point to the working length is an imperative in achieving optimal results.

Good knowledge of the canal morphology is of great importance because it helps to diagnose possible variation in shape, number and location of the canals. Adequate assessment of root canal variations leads to adequate instrumentation as well as successful endodontic treatment and tooth preservation. Complex morphology of root canals of mandibular premolars is usually present bilaterally and from this aspect the preservation of analog tooth from the opposite side should be emphasized.

\section{CONCLUSION}

The most frequent causes of failure in endodontic therapy are untreated and forgotten canals. To achieve success in endodontic treatment practitioners should have in mind, in addition to good knowledge of root canal morphology, also a variability in number and position of the root canals. Mandibular premolar can be very complex for endodontic treatment if there is a variability in the number and shape of the canals. Successful endodontic treatment can be achieved with a combination of instrumentation as well as obturation techniques.

\section{REFERENCES}

1. Krasner Prankov HJ. Anatomy of a pulp chamber floor. J Endod. 2004; 30:5-16.

2. Weine FS. Endodontic Therapy. 3rd ed. Boston, MA: Mosby; 1982.

3. Cohen AS, Brown RC. Pathways of the Pulp. 8th ed. Boston, MA: Mosby; 2002.

4. Hoen MM, Pink FE. Contemporary retreatments endodontic: an analysis based on clinical treatmen findings. J Endod. 2002; 28:834-6.

5. Soares JA, Leonardo RT. Root canal treatment of three rooted maxillary first and second premolars - a case report. Int Endod J. 2003; 36:705-10.

6. Al Fouzan KS. The microscopic diagnosis and treatement of mandibular second premolar with four canals. Int Endod J. 2001; 34:406-10.

7. Lagoudakos TA, Kalogeropulos KS, Kontaikiotis EG. Mandibular second premolar with five root canals. Endod Pract. 2006; 29-31.

8. Vertucci FJ. Root canal anatomy of the human permanent teeth. Oral Surg. 1978; 58:589-99.

9. Vujašković M, Karadžić B, Miletić V. Rooth canal treatment of mandibular second premolar tooth with taurodontism. Srp Arh Celok Lek. 2008; 136(5-6):280-3.

10. Zilich R, Dawson J. Root canal morphology of mandibular first and second premolar. Oral Surg. 1973; 36:738-44.

11. Chan K, Yew SC, Chao SY. Mandibular premolar with three root canals - two cases reports. Int Endod J. 1992; 25:261-4.

12. Rodig T, Hülsmann M. Diagnosis and root canal treatment of a mandibular second premolar with three root canals. Int Endod J. 2003; 36:912-9.

13. Rhodes JS. A case an unusual anatomy: mandibular second premolar with four canals. Int Endod J. 2001; 34:645-8.

14. Martzi E, Zmener O. Five canals in a mandibular second premolar. J Endod. 2000; 26:304-5.

15. Martinez-Lozano MA, Forner-Nvarro L, Sanchez-Cortes JL. Analysis of radiologic factor in determining premolar root canal systems. Oral Surg Oral Med Oral Pathol Oral Radio and Endod. 1999; 88:719-22.

16. Robinson C, Czerny C, Gahleitner A, Bernhardt T, Kainberg FM. Dental CT evaluation of mandibular first molar root canal configuration and variations. Oral Surg Oral Med Oral Pathol Oral Radiol Endod. 2002; 93:328-32.

17. Yosioka T, Villages JC, Kobajachi C, Suda H. Radiographic evaluation of root canal multiplicity in mandibular first premolars. J Endod. 2004; 30:73-4. 


\title{
Endodontsko lečenje donjeg drugog premolara sa tri kanala korena - prikaz dva klinička slučaja
}

\author{
Jugoslav Ilić, Mirjana Vujašković, Ružica Nedeljković \\ Klinika za bolesti zuba, Stomatološki fakultet, Univerzitet u Beogradu, Beograd, Srbija
}

\begin{abstract}
KRATAK SADRŽAJ
Jedan od osnovnih uslova uspešnog endodontskog lečenja je precizna dijagnostika i dobro poznavanje morfologije kanalnog sistema zuba. Donji drugi premolar retko ima više od jednog korena i jednog kanala. Podaci iz literature ukazuju na izuzetno mali procenat donjih drugih premolara sa tri i više kanala korena. Neuobičajeni morfološki izgled kanalnog sistema predstavlja dijagnostički i terapijski izazov. Za postavljanje tačne dijagnoze od izuzetne važnosti su analiza radiograma načinjenog pre hirurškog zahvata i pažljiva eksploracija ulaza u kanale korena. U ovom radu prikazana su dva pacijenta sa trokanalnim donjim drugim premolarima koje je bilo potrebno endodontski lečiti.
\end{abstract}

Ključne reči: mandibularni drugi premolar; anatomska varijacija; endodontsko lečenje

\section{UVOD}

Poznavanje morfologije kanalnog sistema zuba preduslov je za uspešno endodontsko lečenje zajedno sa dobrom procenom primarnog radiograma i pažljivim sondiranjem dna pulpne komore $[1,2]$. Klasičan retroalveolarni snimak nije dovoljan za dijagnostikovanje anomalija i morfoloških varijacija kanala. Ukoliko se u proceni ovakvog radiograma uoči gubitak jasne senke glavnog kanala, treba posumnjati na udvajanje ili na pojavu dodatnih kanala, što zahteva dopunsku analizu i posebnu pažnju pri daljem endodontskom postupku.

Endoterapija podrazumeva mehaničko-medikamentnu obradu celokupnog kanalnog sistema, dezinfekciju, oblikovanje i hermetičku opturaciju uz postavljanje kruničnog ispuna radi prevencije od ponovne infekcije [2,3]. Glavni uzrok neuspeha endoterapije je nedovoljno obrađen kanal korena i neadekvatna opturacija [2]. Uzrok neuspeha mogu biti složeni, neobrađeni ili zaboravljeni kanali $[3,4]$.

Mandibularni premolari su najčešće zubi s jednim korenom i jednim kanalom. Morfološke varijacije u položaju i broju kanala opisane su u oko $30 \%$ slučajeva $[5,6,7]$. Tako je Vertuči (Vertucci) [8] opisao pet tipova donjih premolara. Tip I ima jedan kanal od pulpne komore do vrha zuba; tip II ima jedan kanal koji polazi od pulpne komore, a potom se račva u dva kanala koji se spajaju u jedan u predelu vrha korena; tip III ima dva odvojena kanala od pulpne komore koja se tako završavaju; tip IV podrazumeva jedan kanal koji se u apeksnoj trećini račva u dva odvojena kanala; kod tipa $\mathrm{V}$ se od pulpne komore odvajaju tri odvojena kanala.

Mandibularni drugi premolar obično ima jedan koren i jedan kanal, iako postoje varijacije u broju i morfološkom izgledu kanala i brojna račvanja glavnog kanala u cervikalnoj, srednjoj ili apeksnoj trećini [7, 9]. Vertuči [8] je kod 400 donjih drugih premolara ustanovio jedan kanal u oko 97,5\% uzoraka, dok su dva ili tri kanala zabeležena u 2,5\% uzoraka. U istraživanju Ziliča (Zilich) i Dosona (Dowson) [10], koje je obuhvatilo $938 \mathrm{zu}-$ ba, $12,1 \%$ njih imalo je dva korena ili više, dok su u $0,4 \%$ uzoraka pronađena tri kanala. Donje druge premolare sa tri kanala opisuju i drugi autori $[7,11,12]$. Pojedini autori opisuju donji drugi premolar sa četiri i pet kanala $[6,13]$. Marci (Martzi) i Cmener (Zmener) [14] su opisali jedinstven slučaj sa pet ulaza u kanale u jednom korenu.
Sledi prikaz dva pacijenta s trokanalnim donjim drugim premolarima kod kojih je primenjeno složeno endodontsko lečenje.

\section{PRIKAZ PRVOG SLUČAJA}

Mladić star 24 godine upućen je na Kliniku za bolesti zuba Stomatološkog fakulteta u Beogradu radi endodontskog lečenja drugog donjeg premolara s leve strane. Nije bilo simptoma, a inspekcijom je na krunici uočen privremeni ispun. Perkutorni nalaz ovog zuba bio je blago pozitivan u odnosu na kontrolni zub (prvi premolar s iste strane). Elektrotestom su utvrđeni povišen prag nadražaja i potreba izvođenja terapije kanala korena. Zub je zatim radiografisan, a na preoperacionom snimku uočen je komplikovani korenski sistem (Slika 1).

Tokom iste posete stomatologu data je sprovodna anestezija za odgovarajući donji alveolarni nerv (dvopostotni lidokain i adrenalin 1:200.000; Galenika AD, Srbija), a zatim uklonjen privremeni ispun i načinjena preparacija pristupnog kaviteta ovalnog oblika u bukolingvalnom pravcu. Na dnu pulpne komore jasno su se uočavala dva ulaza u kanale korena koji su bili postavljeni bukalno i lingvalno. Gejts-Glidenovim svrdlima (FKG Dentaire, Švajcarska) ovi ulazi su levkasto prošireni, a K-turpijama \#10 (FKG Dentaire, Švajcarska) eksplorisani bukalni i lingvalni kanal. Potom je načinjen odontometrijski radiogram (Slika 2). Distalna angulacija instrumenta u bukalnom kanalu i na odontometrijskom radiogramu uočena dodatna linijska senka u apeksnom delu bukalnog korena upućivali su na mogućnost postojanja dodatnog kanala. Pristupni kavitet je modifikovan ekstenzijom bukalne ivice u meziodistalnom pravcu, čime je od ovalnog dobio trouglasti oblik (Slika 3). Pažljivom eksploracijom je u bukalnom delu poda pulpne komore pronađen još jedan kanal postavljen mezijalno. Zatim je urađen dopunski snimak sa tri instrumenta radi potvrde položaja kanala korena (Slika 4), čime je u ovom zubu potvrđeno postojanje tri kanala: meziobukalnog, distobukalnog i lingvalnog. Konačna radna dužina za sve kanale je određena apekslokatorom (Raypex 4, VDW, Nemačka).

Kanali su obrađeni ručnim instrumentima (FKG Dentaire, Švajcarska) tehnikom dvostrukog konusa, u obilnoj irigaciji jednoprocentnim rastvorom $\mathrm{NaOCl}$ i uz lubrikaciju preparatom Glyde (Dentsply-Maillefer, Švajcarska). Apeksna preparacija je 
za sva tri kanala završena instrumentom \#25. Kanali su po završenoj preparaciji isprani desetoprocentnom limunskom kiselinom, posušeni papirnim poenima (FKG Dentaire, Švajcarska) i u njih je interseansno nanesen preparat Endocal (Septodont, Francuska), nakon čega je zub privremeno zatvoren sredstvom Citodur $^{\circ}$ (Austria). Sledeća seansa je zakazana za sedam dana. Po uklanjanju privremenog ispuna i interseansnog medikamenta, kanali su isprani jednoprocentnim rastvorom $\mathrm{NaOCl}$, posušeni papirnim poenima i opturisani monokonom tehnikom uz primenu preparata RSA RoekoSeal ${ }^{\circ}$ (Roeko, Nemačka) i gutaperka poena. Na slici 5 je prikazan radiogram zuba sa konačno opturisanim kanalima korena.

\section{PRIKAZ DRUGOG SLUČAJA}

Spontani, blagi, ali dugotrajni bolovi u predelu prvog pretkutnjaka s leve strane razlog su zbog kojeg se pedesetšestogodišnja žena javila na Kliniku za bolesti zuba Stomatološkog fakulteta u Beogradu. Objektivnim pregledom na distalnoj strani sumnjivog zuba uočena je velika karijesna lezija bez perkutorne osetljivosti zuba. Elektrotest je pokazao značajno povišen prag nadražaja pulpe zuba u odnosu na kontrolni, intaktni prvi premolar sa desne strane. Na osnovu dobijenih nalaza postavljena je dijagnoza hroničnog pulpitisa zuba 34 i indikovano endodontsko lečenje. Preoperacioni radiogram je upućivao na složen morfološki izgled ovoga zuba, jer su se uočavale tri periodontalne linije u apeksnom delu zuba, a senke kanala korena na radiogramu su bile višestruke, nejasne i isprekidane (Slika 6). Ovo je ukazivalo i na to da je neophodna posebna opreznost pri izvođenju svih faza endodontskog lečenja, kako bi se izbegle moguće terapijske greške.

Nakon davanja sprovodne anestezije za odgovarajući donji alveolarni nerv (dvoprocentni lidokain i adrenalin 1:200.000; Galenika AD, Srbija), uklonjen je karijes i preparisan pristupni kavitet. Oblik pristupnog kaviteta je modifikovan u trougli u odnosu na, za premolare, uobičajeni ovalni oblik, jer je radiogram ukazivao na tri korena; dakle, i tri ili više kanala. Osnova ovog trouglastog oblika pristupnog kaviteta je formirana bukalno, a vrh oralno. Po uklanjanju koronarnog dela pulpe ulaz u lingvalni kanal je lako prepoznat. Pažljivom eksploracijom K-turpijom \#10 (FKG Dentaire, Švajcarska) utvrđeno je da postoji jedan lingvalni kanal. U bukalnom delu poda pulpne komore nađen je takođe jedan ulaz u kanal, međutim, eksploracijom pomenutim instrumentom duž zidova uočeno je da se pri kraju koronarne trećine kanal deli na dva, od kojih je jedan postavljen mezijalno, a drugi distalno. Peso svrdlima \#4 i \#3 (FKG Dentaire, Švajcarska) levkasto su prošireni ulasci u kanale, pri čemu je bukalni orificijum dodatno proširen, da bi se omogućio pravolinijski pristup kako u mezijalni, tako i u distalni bukalni kanal. Konačna radna dužina za sve kanale je određena apeks-lokatorom (Raypex 4, VDW, Nemačka) i potvrđena odontometrijskim radiogramom (Slika 7).

Koronarne trećine kanala su obrađene Peso svrdlima, a srednje i apeksne ručnim instrumentima (FKG Dentaire, Švajcarska) tehnikom dvostrukog konusa, uz obilnu irigaciju jednoprocentnim rastvorom $\mathrm{NaOCl}$ i lubrikaciju preparatom $\mathrm{Ca}$ nal plus" (Septodont, Francuska). Apeksna preparacija je za sva tri kanala završena instrumentom \#25. Kanali su po završenoj preparaciji isprani desetoprocentnom limunskom kiselinom i posušeni papirnim poenima (FKG Dentaire, Švajcarska), a opturacija je izvedena metodom lateralne kondenzacije uz upotrebu gutaperka poena i paste Acroseal' (Septodo nt, Francuska). Radiogram zuba sa konačno opturisanim kanalima korena prikazan je na slici 8 .

\section{DISKUSIJA}

Anatomske varijacije mandibularnog premolara su dokumentovane u literaturi. Iako su trokanalni premolari izuzetno retki, svaki ovakav premolar se mora pažljivo radiografski i klinički ispitati, da bi se utvrdila ovakva morfologija. Endodontsko lečenje premolara sa tri kanala je visokozahtevan postupak koji od početka do kraja treba da prati predostrožnost.

Početni dijagnostički radiogram je uvod u ovako složen postupak i veoma je važan u dijagnostikovanju višestrukih kanala donjeg premolara $[15,16,17]$. Ukoliko se pažljivo analizira, može se zapaziti da senka glavnog kanala nije izrazito jasna i da postoji sumnja na udvajanje kanala. Mogu se uočiti i više gracilnih kanala. To je indikacija da tretirani zub nema uobičajeni morfološki izgled i da treba obratiti pažnju prilikom formiranja pristupnog kaviteta, pažljivog sondiranja ulaza u kanale korena i njihovog rasporeda. Svakako da bi primena lupe s uveličanjem ili endodontskog mikroskopa bila od izuzetne pomoći u utvrđivanju položaja ulaza u kanale korena.

Prilikom sondiranja poda pulpne komore kod trokanalnog premolara obično je reč o jednom kanalu većeg promera postavljenom lingvalno (oralno) i dva gracilnija postavljena bukalno (bukomezijalni i bukodistalni). U ovom prikazu jedan premolar je imao tri korena (lingvalni, bukomezijalni i bukodistalni) i isto toliko kanala, a drugi dva korena (lingvalni i bukalni), dok su u bukalnom korenu bila dva kanala (bukodistalni i bukomezijalni). U ovakvim slučajevima kanali su gracilni, teže prohodni, pa se za ispitivanje prohodnosti uglavnom koriste tanki kanalni instrumenti 08 i 10 uz primenu lubrikanta, radi lakše prohodnosti celom dužinom kanala. Uglavnom se prave dva radiograma, pri čemu je drugi mezijalno ili distalno pomeren za oko 30 stepeni, da se kanali ne bi superponirali.

Ovako složena morfologija pored precizne dijagnostike zahteva i pažljivu endodontsku obradu i odontometriju uz kombinaciju radiografske metode, pri kojoj se vrši pozicioniranje kanalnih instrumenata u kanale i pomeranje ugla snimanja da bi se izbegla superpozicija i registrovala radna dužina. Provera odontometrije apeks-lokatorom je značajna, jer je reč o preciznijoj metodi, a može da smanji i broj radiograma. Mašinsko širenje ulaza u kanale omogućava pravolinijsko unošenje kanalnih instrumenata pri obradi, što je takođe veoma značajno, posebno kod udvajanja kanala, budući da se time ublažava krivina kanala i zalazi u zakrivljeni apeksni deo. Odgovarajuća opturacija i pravilan odabir glavnih gutaperka poena na radnu dužinu obavezni su za postizanje optimalne opturacije ovako gracilnih i udvojenih kanala.

Dobro poznavanje morfologije kanalnog sistema je izuzetno važno, jer je to uvod u eventualnu varijaciju u obliku, broju i rasporedu kanala. Blagovremeno sagledavanje varijacija i adekvatna endodontska obrada vodi uspešnom endodontskom lečenju i očuvanju zuba. Složen morfološki izgled kanala i korenova donjih premolara obično se javlja s obe strane, te bi s tim u vezi trebalo naglasiti potrebu očuvanja istoimenog zuba 
sa suprotne strane, kako ne bi došlo do ireverzibilnih promena pulpe i endodontskog zbrinjavanja koje je u ovakvoj situaciji složeno i neizvesno.

\section{ZAKLJUČAK}

Jedan od glavnih uzroka neuspeha endodontskog lečenja su neobrađeni i zaboravljeni kanali. Praktičari, osim dobrog poznavanja morfologije kanala korena zuba, moraju imati na umu promenljivost broja i položaja kanala korena, da bi se zub endodontski uspešno zbrinuo. Mandibularni premolar može da bude vrlo složen za endotretman ukoliko postoje varijabilnosti u broju i obliku kanala. To zahteva i pažljiviju endodontsku obradu uz kombinaciju tehnika, kako pri obradi, tako i prilikom opturacije ovakvih kanalnih sistema. 